\title{
SNAKEBITES BY Crotalus durissus ssp IN CHILDREN IN CAMPINAS, SÃO PAULO, BRAZIL
}

\author{
Fábio BUCARETCHI(1,5), Sílvia Regina Fontoura HERRERA(2), Stephen HYSLOP(3), Emílio Carlos Elias BARACAT(1) \& Ronan José VIEIRA(4,5)
}

\begin{abstract}
SUMMARY
From January, 1984 to March, 1999, 31 children under 15 y old (ages 1-14 y, median 8 y) were admitted after being bitten by rattlesnakes (Crotalus durissus ssp). One patient was classified as "dry-bite", 3 as mild envenoming, 9 as moderate envenoming and 18 as severe envenoming. Most patients had neuromuscular manifestations, such as palpebral ptosis (27/31), myalgia (23/31) and weakness (20/31). Laboratory tests suggesting rhabdomyolysis included an increase in total blood creatine kinase (CK, 28/29) and lactate dehydrogenase (LDH, 25/25) levels and myoglobinuria (14/15). The main local signs and symptoms were slight edema (20/ 31 ) and erythema (19/31). Before antivenom (AV) administration, blood coagulation disorders were observed in $20 / 25$ children that received AV only at our hospital (incoagulable blood in 17/25). AV early reactions were observed in 20 of these 25 cases (9/9 patients not pretreated and 11/16 patients pretreated with hydrocortisone and histamine $\mathrm{H}_{1}$ and $\mathrm{H}_{2}$ antagonists). There were no significant differences in the frequency of patients with AV early reactions between the groups that were and were not pretreated (Fisher's exact test, $\mathrm{p}=0.12$ ). Patients admitted less than and more than $6 \mathrm{~h}$ after the bite showed the same risk of developing severe envenoming (Fisher's exact test, $\mathrm{p}=1)$. No children of the first group $(<6 \mathrm{~h})$ showed severe complications whereas $3 / 6$ children admitted more than $6 \mathrm{~h}$ post-bite developed acute renal failure. Patients bitten in the legs had a higher risk of developing severe envenoming (Fisher's exact test, $\mathrm{p}=0.04$ ). There was a significant association between both total CK and LDH blood enzyme levels and severity ( $<<0.001$ for $\mathrm{CK}$ and $\mathrm{p}<0.001$ for LDH; Mann-Whitney U test). No deaths were recorded.
\end{abstract}

KEYWORDS: Antivenom; Children; Crotalus durissus ssp; Rhabdomyolysis; Snakebites

\section{INTRODUCTION}

The South American rattlesnake (Crotalus durissus ssp) is one of the most dangerous venomous snakes of Brazilis,8. According to the Brazilian Ministry of Health, from 1990 to 1993, bites by Crotalus durissus ssp accounted for $7.7 \%$ of the 65,911 accidents involving snakes in which the genus was known or suspected, with a lethality rate of $1.9 \%$, the highest among the genera of venomous Brazilian snakes ${ }^{5}$. These accidents have been described mainly in the states of Minas Gerais and São Paulo (southeastern Brazil), with $C$. d. terrificus being the subspecies most frequently implicated ${ }^{1,8,14}$. Acute renal failure and acute respiratory failure are the main causes of death in such envenomations $\mathrm{s}^{3,20}$.

The venom of $C$. $d$. terrificus contains a variety of toxic proteins, including crotoxin, crotamine, gyroxin, convulxin and a thrombin-like enzyme $^{15,17,25}$. Clinically, the most important of these toxins is crotoxin, which accounts for at least $50 \%$ of the venom protein ${ }^{17}$. Crotoxin is a potent presynaptic neurotoxin that acts at the neuromuscular junction to produce neuromuscular blockade and progressive flaccid paralysis (acute myasthenic syndrome) of variable intensity ${ }^{17,25}$. Crotoxin may also induce severe and selective skeletal muscle injury (rhabdomyolysis) in which only muscles or muscle regions composed of oxidative type I and IIA fibers are injured ${ }^{10,17,22}$. The thrombin-like component of $C$. $d$. terrificus venom can cause hypofibrinogenemia or complete fibrinogen consumption, resulting in partial or complete blood incoagulability in envenomed patients ${ }^{15,21}$. A platelet-aggregating factor has also been isolated from the venoms of $C$. d. terrificus and C. d. cascavella ${ }^{15}$. However, thrombocytopenia has rarely been detected in envenomed patients $^{21}$, although this may reflect the relatively small amount of this component present in the venom ${ }^{15}$.

Twenty-one percent of snakebites in Brazil occur in patients under 15 years old ${ }^{4}$. However, only two studies, published by the same authors, have described the clinical and laboratory aspects of $C$. $d$. terrificus snakebites in a case series of children (10 to 21 patients) in Brazil ${ }^{9,11}$. The present report describes the clinical and some laboratory aspects of bites caused by $C$. durissus ssp in 31 children less than 15 y old admitted to the University Hospital of the State University of Campinas (UNICAMP) in Campinas, São Paulo state.

\section{PATIENTS AND METHODS}

The hospital records of 31 patients admitted to the University Hospital at UNICAMP were collected prospectively over a 16-year period

(1) Departamento de Pediatria, Faculdade de Ciências Médicas, Universidade Estadual de Campinas (UNICAMP), Campinas, SP, Brasil.

(2) Aluna do 6o ano da XXXV Turma da Faculdade de Ciências Médicas, Universidade Estadual de Campinas (UNICAMP), Campinas, SP, Brasil.

(3) Departamento de Farmacologia, Faculdade de Ciências Médicas, Universidade Estadual de Campinas (UNICAMP), Campinas, SP, Brasil.

(4) Departamento de Clínica Médica, Faculdade de Ciências Médicas, Universidade Estadual de Campinas (UNICAMP), Campinas, SP, Brasil.

(5) Centro de Controle de Intoxicações, Faculdade de Ciências Médicas e Hospital das Clínicas, Universidade Estadual de Campinas (UNICAMP), Campinas, SP, Brasil.

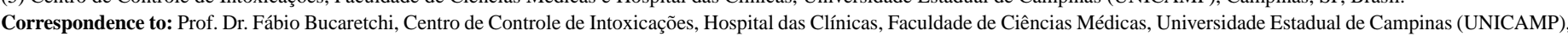
CP 6111, 13083-970 Campinas, SP, Brasil. Fax-Phone: 55-19-3788-8670. E-mail: bucaret@ fcm.unicamp.br 
(January, 1984 - March, 1999). Six of these 31 patients had received initial treatment at other centers before transferred to UNICAMP. The diagnosis was based on the envenoming syndrome and/or snake identification.

In all cases, information on the time, day and month of bite, as well as the patient's age, sex and geographic residence were recorded. The place where the bite occurred, as well as the anatomical site of the bite, the application of first aid, the time elapsed between the bite and medical treatment, the local and systemic signs and symptoms observed, the severity of envenoming, the treatment administered upon admission [including medication prior to antivenom (AV) infusion], the number of vials of $\mathrm{AV}$ and any associated reaction to $\mathrm{AV}$, and the subsequent outcome of the cases were noted.

Following posterior review, the accidents were classified according to the Brazilian Ministry of Health recommendations ${ }^{5}$ : mild- delayed mild neurotoxic signs and symptoms without myalgia or urine color alteration; moderate- mild neurotoxic signs and symptoms observed early after the bite, possibly associated with light myalgia and slightly dark urine; severe- acute myasthenic syndrome is evident (palpebral ptosis and weakness) associated with generalized myalgia and dark brown urine. Oliguria and anuria may be also present in severe cases. Blood coagulation disorders may be observed in mild, moderate or severe envenoming. The accidents were also classified as dry-bites when the children did not present local or systemic clinical manifestations and showed normal laboratory tests ${ }^{19,24}$.

The whole blood clotting time $\mathrm{s}^{5}$ and/or prothrombin, thrombin and activated partial thromboplastin times (using commercial reagents kits) were determined. A whole blood clotting time between $10 \mathrm{~min}$ and 30 min was considered prolonged, whereas a time greater than $30 \mathrm{~min}$ represented incoagulable blood (Rosenfeld, G., 1965, apud ${ }^{5}$ ). Total blood creatine kinase $(\mathrm{CK})$ and lactate dehydrogenase $(\mathrm{LDH})$ activities were also determined using commercial kits. These results were expressed as the ratio between the encountered value and the upper limit of the reference value. Myoglobinuria was determined using the latex agglutination test (Rapitex®, Behring Laboratories, Germany).

When required, the patients received polyspecific, hyperimmune equine crotalic AV (10 ml/vial, produced by the Instituto Butantan, São Paulo, SP; the Fundação Ezequiel Dias, Belo-Horizonte, MG; and the Instituto Vital Brazil, Rio de Janeiro, RJ, Brazil) i.v. over 20-30 min. One milliliter of $\mathrm{AV}$, which consists mainly of the $\mathrm{F}(\mathrm{ab})_{2}$, fragment of immunoglobulins, neutralizes $1.5 \mathrm{mg}$ of $C$. d. terrificus venom in a standard mouse assay. From November, 1989, to March, 1999, all patients who received crotalic AV only at UNICAMP $(\mathrm{N}=16)$ were pretreated with histamine $\mathrm{H}_{1}$ and $\mathrm{H}_{2}$ antagonists such as clorpheniramine $(0.05$ $\mathrm{mg} / \mathrm{kg})$, cimetidine $(10 \mathrm{mg} / \mathrm{kg})$ or ranitidine $(3 \mathrm{mg} / \mathrm{kg})$ i.v. or i.m., and hydrocortisone i.v. (10 mg/kg) at least $15 \mathrm{~min}$ before $\mathrm{AV}$ infusion ${ }^{5,6,12}$.

A database was constructed to obtain the frequency distribution of the variables studied, using the software program Epi-Info version 6.04 (Centers for Disease Control, Atlanta, GA, USA). Differences between the frequencies of some variables were compared using Fisher's exact probability test. The significance of the differences in the total CK and LDH levels between the groups classified as moderate and severe was evaluated using the Mann-Whitney U test. Some of these results (first measurement of CK and LDH) are shown as box and whisker plots. In each plot, the upper and lower short horizontal lines indicate the maximum and minimum values observed, respectively. The median, first and third quartiles of the CK and LDH values of each group correspond to the intermediate, lower and upper horizontal lines used to construct each rectangle, respectively. A p value $<0.05$ was considered to indicate significance.

\section{RESULTS}

The offending snake was brought for identification to the level of species in ten of the 31 cases.

The patients' age ranged from $1 \mathrm{y}$ to $14 \mathrm{y}$ (median $=8 \mathrm{y}$, mean $\pm \mathrm{SD}$ $=8.7 \pm 3.4 \mathrm{y})$. Most accidents involved male victims $(25 / 31)$ and occurred between 13:00 h and 19:00 h (17/31), from November to April (24/31), in rural areas, including around the home.

Lower limbs were the most commonly bitten $(\mathrm{N}=28 / 31$; feet, $\mathrm{N}=$ 12; legs, $\mathrm{N}=9$ and ankles, $\mathrm{N}=7$ ). A tourniquet was used in six of the 31 cases.

Table 1 summarizes the main clinical features in this case series. Most of the patients showed systemic manifestations of neuromuscular involvement. Local signs and symptoms, mainly slight edema and erythema, were also observed. No deaths were recorded.

Myoglobinuria was detected in most children studied ( $N=14 / 15$; moderate, $3 / 3$ and severe, 11/12). The sequential measurements of total CK and LDH levels (up to $114 \mathrm{~h}$ post-bite) in children classified as moderate and severe envenoming are shown in Fig. 1. These data suggest varying degrees of skeletal muscle damage in all children with a significant difference in the $\mathrm{CK}$ and $\mathrm{LDH}$ levels between these two groups of patients, either for the first measurement [Fig. 2A (CK), p = 0.04; Fig. 2B $(\mathrm{LDH}), \mathrm{p}=0.03$; Mann-Whitney $\mathrm{U}$ test] or for sequential measurements $(\mathrm{CK}, \mathrm{p}<0.001$ and LDH, $\mathrm{p}<0.001$; Mann-Whitney $\mathrm{U}$ test). No skeletal muscle biopsy was performed.

Blood coagulation disorders upon hospital admission were observed in 20 of the 25 children who received AV only at UNICAMP (incoagulable blood in 17/25, Table 2). All children with severe envenoming showed coagulation disorders. Most of these children (19/ 25 ) received AV less than $6 \mathrm{~h}$ after the bite. Patients admitted less than and more than $6 \mathrm{~h}$ after the bite showed the same risk of developing severe envenoming [severe $(\mathrm{N}=12)$ vs mild and moderate $(\mathrm{N}=13)$ cases; Fisher's exact test, $p=1$, Table 2]. No children of the first group $(<6 \mathrm{~h})$ showed severe complications whereas $3 / 6$ children admitted more than $6 \mathrm{~h}$ post-bite developed acute renal failure, with two requiring dialysis (Table 1).

AV early reactions were observed in 20 of the 25 children who received AV only at UNICAMP, and were less frequent in children pretreated with histamine $\mathrm{H}_{1}$ and $\mathrm{H}_{2}$ antagonists and hydrocortisone. However, there was no significant difference in the frequency of $\mathrm{AV}$ early reactions between pretreated and non-pretreated groups (Fisher's exact test, $p=0.12$, Table 2). A similar frequency of AV early reactions per individual was observed in both groups, with most of these reactions being considered mild (Table 3 ). Five patients (three pretreated with the above scheme) developed severe early reactions with dyspnea $(\mathrm{N}=4)$, 
Table 1

The main features of bites according to the severity of envenoming in 31 children bitten by $C$. durissus ssp

\begin{tabular}{|c|c|c|c|c|c|}
\hline Features & $\begin{array}{c}\text { Dry-bite } \\
\mathrm{N}=1\end{array}$ & $\begin{array}{l}\text { Mild } \\
\mathrm{N}=3\end{array}$ & $\begin{array}{c}\text { Moderate } \\
\mathrm{N}=9\end{array}$ & $\begin{array}{l}\text { Severe } \\
\mathrm{N}=18\end{array}$ & $\begin{array}{c}\text { Total } \\
\mathrm{N}=31\end{array}$ \\
\hline \multicolumn{6}{|l|}{ Bite site } \\
\hline Edema & 0 & 2 & 7 & 11 & 20 \\
\hline Erythema & 1 & 0 & 4 & 14 & 19 \\
\hline Pain & 0 & 2 & 4 & 9 & 15 \\
\hline Paresthesia & 0 & 1 & 0 & 2 & 3 \\
\hline \multicolumn{6}{|l|}{ Systemic manifestations } \\
\hline Palpebral ptosis & 0 & 0 & 9 & 18 & 27 \\
\hline Prostration & 0 & 0 & 7 & 16 & 23 \\
\hline Myalgia & 0 & 0 & 7 & 16 & 23 \\
\hline Tachycardia & 0 & 0 & 7 & 13 & 20 \\
\hline Weakness & 0 & 1 & 6 & 13 & 20 \\
\hline Dark urine & 0 & 1 & 2 & 14 & 17 \\
\hline Mydriasis & 0 & 0 & 5 & 12 & 17 \\
\hline Vomiting & 0 & 0 & 4 & 9 & 13 \\
\hline Diplopia & 0 & 0 & 3 & 8 & 11 \\
\hline Superficial breathing & 0 & 0 & 0 & 6 & 6 \\
\hline Diaphoresis & 0 & 0 & 1 & 4 & 5 \\
\hline Anisocoria & 0 & 0 & 0 & 2 & 2 \\
\hline Myosis & 0 & 0 & 0 & 1 & 1 \\
\hline Bleeding & 0 & 0 & 0 & 1 & 1 \\
\hline Tetany & 0 & 0 & 0 & 1 & 1 \\
\hline \multicolumn{6}{|l|}{ Complications } \\
\hline Acute renal failure & 0 & 0 & 0 & 3 & 3 \\
\hline Local infection (celluliti & tis) 0 & 0 & 0 & 2 & 2 \\
\hline $\mathrm{AV}^{*}$ before UNICAMP & 0 & 0 & 0 & 3 & 3 \\
\hline $\begin{array}{l}\text { AV before and } \\
\text { at UNICAMP }\end{array}$ & 0 & 0 & 0 & 3 & 3 \\
\hline AV only at UNICAMP & 1 & 3 & 9 & 12 & 25 \\
\hline
\end{tabular}

$* \mathrm{AV}=$ antivenom

bradycardia $(\mathrm{N}=3)$, arterial hypotension $(\mathrm{N}=3)$, wheezes $(\mathrm{N}=2)$ and stridor $(\mathrm{N}=1)$ (Table 4). No late $\mathrm{AV}$ reactions were observed.

\section{DISCUSSION}

In most of the cases reported here, diagnosis was based on the anamnesis plus the clinical manifestations and laboratory tests which suggested envenoming by $C$. durissus ssp. All the bites were probably caused by $C$. $d$. terrificus, the only subspecies routinely identified in the geographical area studied ${ }^{3,8,14}$.

That accidents were more common from November to April generally reflected the influence of seasonal factors such as an increase in temperature and humidity and in human activity in rural areas ${ }^{8,14}$. In contrast to the Brazilian Ministry of Health data ${ }^{5}, 30 \%$ of venomous snakebites in children admitted to our service from 1984 to 1999 were caused by $C$. durissus ssp. A similar frequency was reported by CUPO et al. in Ribeirão Preto, $\mathrm{SP}^{11}$.
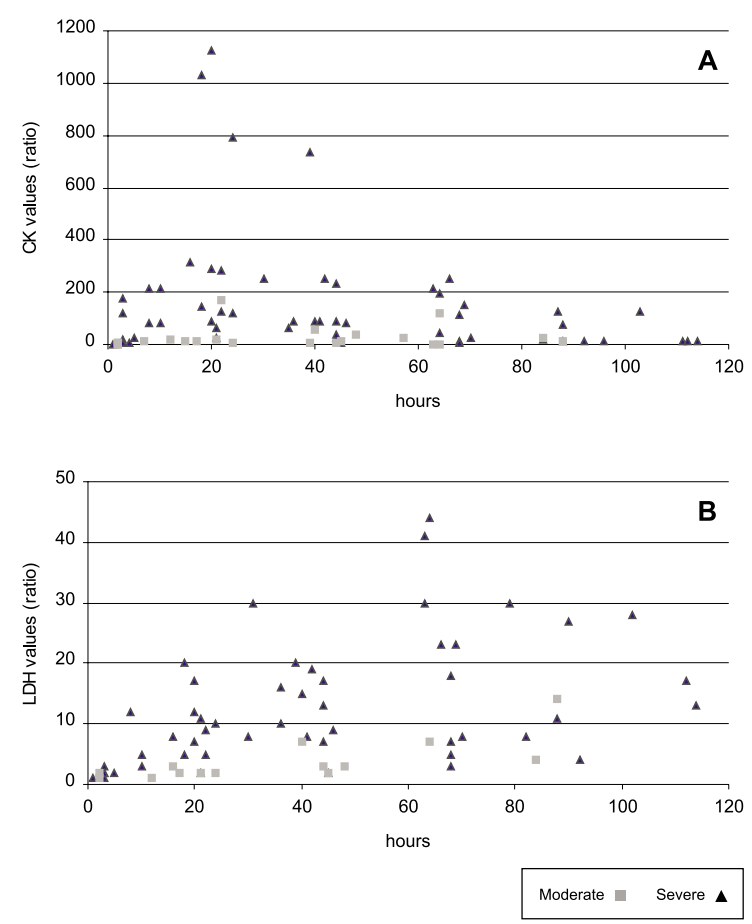

Fig. 1 - Scatter plot of the sequential results of total CK (A) and LDH (B) enzyme activities* in 27 children classified as moderate $(\mathrm{N}=9)$ and severe $(\mathrm{N}=18)$ envenoming up to $114 \mathrm{~h}$ post-bite by $C$. durissus ssp.

*The individual results are presented as the ratio between the encountered value and the upper limit of the reference value. $\mathrm{CK}=$ creatine kinase, $\mathrm{LDH}=$ lactate dehydrogenase. There was a statistical difference between moderate and severe cases based on the sequential results for total CK and LDH (CK, p < 0.001; LDH, p < 0.001; Mann-Whitney U test). There was no statistical difference between moderate and severe cases when the interval between the bite and the time of sample collection for analysis were compared (CK, p $=0.36$; LDH, p $=0.18$; Mann-Whitney U test).

The high frequency of bites involving the legs $(\mathrm{N}=9 / 31)$ may be related to accidents caused by adult snakes ${ }^{14}$. Patients bitten in the legs had a higher risk of developing severe envenoming [severe $(\mathrm{N}=8 / 18)$ vs non-severe cases ("dry-bite", mild and moderate, $N=1 / 13$ ), Fisher's exact test, $\mathrm{p}=0.04]$. Although six patients had used tourniquets, no benefit of this procedure has been demonstrated in patients bitten by $C$. durissus ssp in Brazil ${ }^{1}$.

One case classified as a "dry-bite", in which the snake was brought for identification, was admitted $4 \mathrm{~h}$ after the bite and received AV. Such patients should be correctly diagnosed and observed for at least 12-24 h but should not be treated unnecessarily with sometimes hazardous $\mathrm{AV}^{19,24}$, like the case above.

As reported elsewhere ${ }^{9,11}$, most of the children were classified as having severe envenoming and showed clinical manifestations of neuromuscular involvement plus biochemical evidence of skeletal muscle damage within $6 \mathrm{~h}$ after the bite. The severity classification used was essentially based on clinical aspects 5 . In addition, the present results indicated a significant association between severity and blood enzyme levels (total CK and LDH, Fig. 1 and 2). As also observed by CUPO et $a l .{ }^{10}$, increased levels of both CK and LDH were observed early on, with 

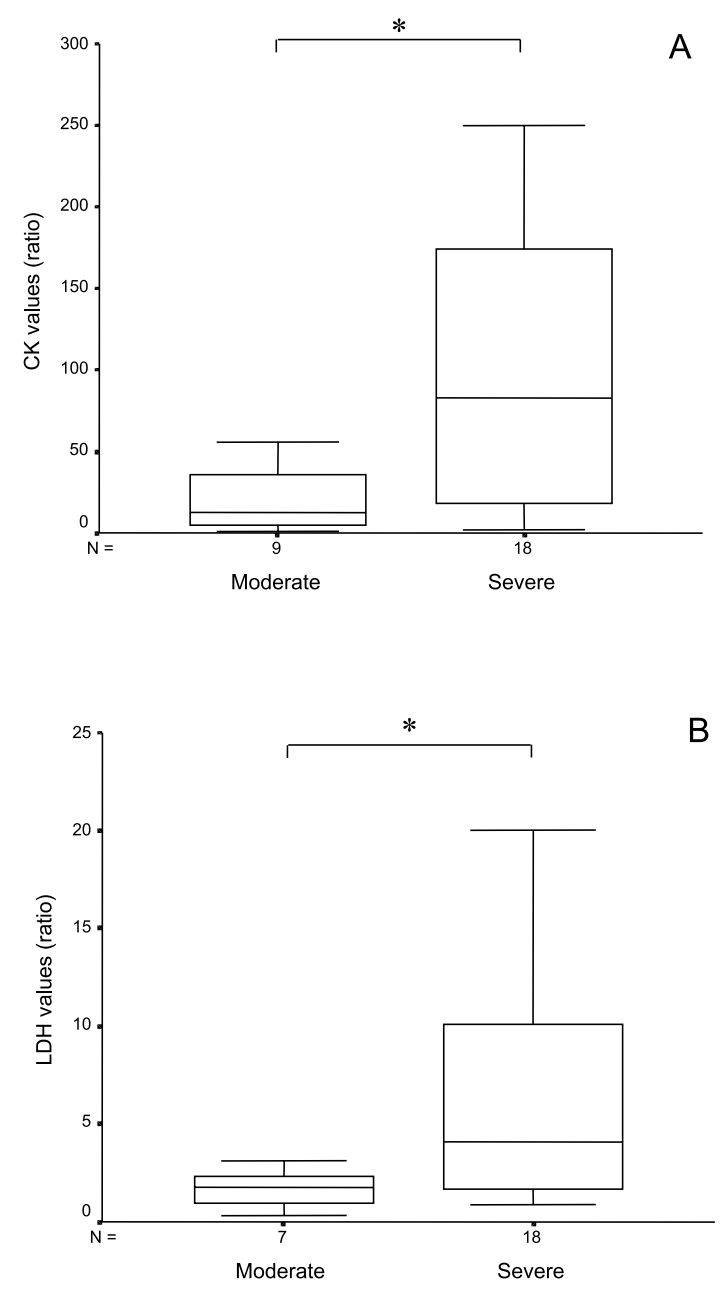

Fig. 2 - Comparison of the results of the first measurement of total CK (A) and LDH (B) activities between moderate and severe cases of envenoming in children bitten by $C$. durissus ssp.

$\mathrm{CK}=$ creatine kinase, $\mathrm{LDH}=$ lactate dehydrogenase. The data are shown as box and whisker plots. ${ }^{\mathrm{p}} \mathrm{p}<0.05$ for the comparisons indicated at the top of the panel (Mann-Whitney U test). The individual results represent the ratio between the encountered value and the upper limit of the reference value. There was no statistical difference between moderate and severe cases when the interval between the bite and the time of sample collection for analysis were compared (CK, p = 0.46; LDH, p = 0.61; Mann-Whitney U test).

a more rapid rise and decline in CK compared to LDH (Fig. 1). Although not shown in the results, 8 out of 20 patients developed hypocalcemia, only one of which was symptomatic (tetany, Table 1). Hypocalcemia should always be monitored in patients with intense rhabdomyolysis since it is a common complication in this situation ${ }^{3,11}$.

Although only one patient presented systemic bleeding, the frequency of blood coagulation disorders among the patients who received AV only at UNICAMP $(\mathrm{N}=20 / 25)$ was greater than observed after Bothrops spp snakebites in children $(\mathrm{N}=34 / 56)$ during the same period ${ }^{7}$. Systemic bleeding is rarely observed after bites by $C$. durissus $\mathrm{ssp}^{14,21}$, in contrast to accidents caused by Bothrops $\mathrm{spp}^{7}$, probably because of the lack of hemorrhagic activity in $C$. d. terrificus venom ${ }^{15}$. The high frequency of

\section{Table 2}

The interval between bite and hospital admission and the frequency of blood coagulation disorders and antivenom early reactions (with and without pretreatment) according to the severity of envenoming in 25 children bitten by $C$. durissus ssp who received antivenom only at UNICAMP

\begin{tabular}{|c|c|c|c|c|c|}
\hline Features & $\begin{array}{c}\text { Dry-bite } \\
\mathrm{N}=1\end{array}$ & $\begin{array}{l}\text { Mild } \\
\mathrm{N}=3\end{array}$ & $\begin{array}{c}\text { Moderate } \\
\mathrm{N}=9\end{array}$ & $\begin{array}{l}\text { Severe } \\
\mathrm{N}=12\end{array}$ & $\begin{array}{c}\text { Total } \\
\mathrm{N}=25\end{array}$ \\
\hline \multicolumn{6}{|l|}{ Admission (h after bite) } \\
\hline$<3 \mathrm{~h}$ & - & 3 & 5 & 4 & 12 \\
\hline $3-6 h$ & 1 & - & 1 & 5 & 7 \\
\hline$>6 \mathrm{~h}$ & - & - & 3 & 3 & 6 \\
\hline \multicolumn{6}{|l|}{ Coagulation } \\
\hline Not determined & - & 1 & 0 & 0 & 1 \\
\hline Normal & 1 & 1 & 2 & 0 & 4 \\
\hline Altered & - & 1 & 7 & 12 & 20 \\
\hline (incoagulable) & & $(0)$ & (6) & (11) & (17) \\
\hline Crotalic AV* (ml) & 60 & $90-100$ & $70-200$ & $100-200$ & \\
\hline Median (ml) & 60 & 100 & 100 & 200 & 170 \\
\hline Early reactions & $1 / 1$ & $2 / 3$ & $8 / 9$ & $9 / 12$ & $20 / 25$ \\
\hline (with pretreatment) $\dagger$ & - & $(0 / 1)$ & $(5 / 6)$ & $(6 / 9)$ & $(11 / 16)$ \\
\hline (without pretreatment) & $(1 / 1)$ & $(2 / 2)$ & $(3 / 3)$ & $(3 / 3)$ & $(9 / 9)$ \\
\hline
\end{tabular}

$* \mathrm{AV}=$ antivenom; $\dagger=$ Pretreatment with histamine $\mathrm{H}_{1}$ and $\mathrm{H}_{2}$ antagonists and hydrocortisone.

Table 3

Antivenom early reactions in 20 children bitten by $C$. durissus ssp snakes who received antivenom only at UNICAMP. Eleven patients were pretreated with histamine $\mathrm{H}_{1}$ and $\mathrm{H}_{2}$ antagonists and hydrocortisone

\begin{tabular}{lccc}
\hline Early reaction & $\begin{array}{c}\text { Pretreated } \\
\mathrm{N}=11\end{array}$ & $\begin{array}{c}\text { Not pretreated } \\
\mathrm{N}=9\end{array}$ & $\begin{array}{c}\text { Total } \\
\mathrm{N}=20\end{array}$ \\
\hline Urticaria & 7 & 6 & 13 \\
Tremors & 3 & 3 & 6 \\
Cardiac arrhythmias & 3 & 1 & 4 \\
Dyspnea & 2 & 2 & 4 \\
Cough & 2 & 1 & 3 \\
Vomiting & 1 & 2 & 3 \\
Morbiliform rash & 1 & 2 & 3 \\
Hypotension & 1 & 2 & 3 \\
Bradycardia & 2 & 1 & 3 \\
Flushing & 2 & 0 & 2 \\
Abdominal pain & 1 & 1 & 2 \\
Wheezes & 2 & 0 & 2 \\
& & & \\
Palpebral edema & 2 & 0 & 2 \\
Tachycardia & 1 & 1 & 2 \\
Stridor & 1 & 0 & 1 \\
Facial edema & 1 & 0 & 1 \\
Others & 2 & 1 & 3 \\
TOTAL & $\mathbf{3 4}$ & $\mathbf{2 3}$ & $\mathbf{5 7}$ \\
ER* per individual & $\mathbf{3 . 1}$ & $\mathbf{2 . 6}$ & $\mathbf{2 . 9}$ \\
\hline
\end{tabular}

*ER = early reaction (mean) 
blood coagulation disorders in children bitten by $C$. durissus ssp may reflect the severity of envenoming in this age group, with possible additional effects secondary to the powerful myotoxic action of the venom ${ }^{21}$.

Soft-tissue infection has been frequently observed after severe Bothrops spp snakebites in children ${ }^{7}$. Although anaerobes and Gram negative bacteria have been isolated from the venom and oral cavities of South American rattlesnakes ${ }^{17}$, local infection following envenoming are rare, perhaps because $C$. durissus terrificus venom causes only minor local tissue damage ${ }^{17}$.

Although patients admitted less than and more than $6 \mathrm{~h}$ after the bite showed the same risk of developing severe envenoming, no severe complications were observed in the first group $(<6 \mathrm{~h})$. On the other hand, all of the children who developed acute renal failure $(\mathrm{N}=3)$ received $\mathrm{AV}$ more than $9 \mathrm{~h}$ after the bite. Acute renal failure is the main complication and cause of death after $C$. durissus ssp snakebites ${ }^{3,5,9-}$ $11,14,20,23$, and an increased risk of renal failure has been correlated with the interval between the bite and receiving medical help $p^{23}$. These results suggest a greater efficacy for AV administered soon after a bite in association with other supportive measures (intravenous fluids, sodium bicarbonate and diuretics such as furosemide or mannitol) to prevent acute tubular necrosis secondary to rhabdomyolysis. This approach should provide a good hydration with a diuresis higher than $2 \mathrm{ml} / \mathrm{kg} / \mathrm{h}$ and a urinary $\mathrm{pH}$ of $7.0-8.0^{5,11}$.

AV early reactions observed in the present case series $(N=20 / 25)$ were more severe and more frequent than those seen after Bothrops spp snakebites in children $(\mathrm{N}=25 / 56)^{7}$ during the same period. This could be related partly to the amount of crotalic AV infused (median $=170 \mathrm{ml}$ ) compared with bothropic AV (median $=60 \mathrm{ml}$ ), and with the type of $\mathrm{AV}^{5,6,26}$. Considering these AV reactions, recombinant antibodies against crotoxin from $C$. $d$. terrificus venom may represent an interesting therapeutic alternative as a safer $\mathrm{AV}^{2}$, although this needs to be confirmed in clinical trials. However, the large scale manufacturing of these products tends to be very expensive. Although a higher frequency of AV early reactions was observed in patients not pretreated with histamine $\mathrm{H}_{1}$ and $\mathrm{H}_{2}$ antagonists and hydrocortisone, statistical analysis suggested that such treatment was not efficient. However, since the present study is not a randomized, placebocontrolled trial, its methodological limitations preclude conclusions about the real efficacy of the pretreatment scheme used here. Recent randomized, double-blind clinical studies have shown a significant reduction in AV early reactions in patients pretreated with adrenaline s.c. in Sri-Lanka ${ }^{18}$, as well as an inability of promethazine i.m. in preventing AV early reactions in patients who received bothropic $\mathrm{AV}^{13}$.

In conclusion, most accidents caused by $C . d$. terrificus in children are severe. The prognosis can be good, as long as the children receive prompt medical care, including adequate $\mathrm{AV}$ prescription and hydration, as well as correct treatment for the main complications.

\section{RESUMO}

\section{Acidentes por serpentes Crotalus durisssus ssp em crianças em Campinas, São Paulo, Brasil}

De janeiro de 1984 a março de 1999, 31 crianças com menos de 15 anos de idade (1 a 14 anos, mediana $=8$ anos) foram admitidas após terem sido picadas por Crotalus durissus ssp. Uma criança não apresentou manifestações clínicas de envenenamento, enquanto 3 foram classificadas como acidente leve, 9 como moderado e 18 como grave. A maioria das crianças apresentou envolvimento neuromuscular, tais como ptose palpebral (27/31), mialgia (23/31) e fraqueza (20/31). Alterações laboratoriais sugerindo rabdomiólise também foram observadas, como aumento das enzimas séricas CK (28/29) e LDH (25/25) e mioglobinúria (14/15). As principais manifestações locais observadas foram edema discreto (20/31) e eritema (19/31). Alterações da coagulação, antes da administração da soroterapia antiveneno (SAV), foram observadas em 20 das 25 crianças que receberam a SAV exclusivamente em nosso hospital (sangue incoagulável em 17/25). Reações precoces à SAV foram observadas em 20 destes 25 casos, em todos os pacientes não pré-tratados $(\mathrm{N}=9)$ e em 11 dentre os 16 pré-tratados com antagonistas $\mathrm{H}_{1}$ e $\mathrm{H}_{2}$ da histamina e hidrocortisona. Não foram constatadas diferenças estatísticas significativas comparando-se a frequiência de reações precoces à SAV entre os grupos que receberam ou não o pré-tratamento (teste exato de Fisher, $p=0,12$ ). Pacientes atendidos com menos ou mais de 6 horas após o acidente apresentaram o mesmo risco quanto a evolução para casos graves (teste exato de Fisher, $\mathrm{p}=1$ ), não se observando complicações graves no $1^{\circ}$ grupo $(<6 \mathrm{~h})$, enquanto $3 / 6$ admitidos mais de 6 horas após a picada evoluíram com insuficiência renal aguda. Pacientes picados na perna apresentaram um maior risco de desenvolver acidentes graves (teste exato de Fisher, $\mathrm{p}=0,04$ ). Houve uma associação significativa entre os níveis séricos das enzimas CK e LDH total e gravidade (teste U de Mann-Whitney, CK, p < 0,001; LDH, p < 0,001). Nenhum óbito foi registrado.

\section{ACKNOWLEDGEMENTS}

Silvia R.F. Herrera was the recipient of a PIBIC/CNPq-PRPUNICAMP (1999-2000) scholarship. The authors thank Maria T. de Oliveira (CCI-UNICAMP) and Ricardo M. Pereira (Departamento de Pediatria-UNICAMP) for their technical assistance.

\section{REFERENCES}

1. AMARAL, C.F.S.; CAMPOLINA, D.; DIAS, M.B.; BUENO. C.M. \& REZENDE, N.A. - Tourniquet ineffectiveness to reduce the severity of envenoming after Crotalus durissus sp snake bite in Belo Horizonte, Minas Gerais, Brazil. Toxicon, 36: 805808, 1998.

2. ANTIOFÍDICO de cascavel fica mais leve. Pesq. Fapesp, 55: 40-41, 2000.

3. AZEVEDO-MARQUES, M.M.; CUPO, P.; COIMBRA, T.M. et al. - Myonecrosis, myoglobinuria, and acute renal failure induced by the South American rattlesnake (Crotalus durissus terrificus) envenomation in Brazil. Toxicon, 23: 631-636, 1985.

4. BRASIL. MINISTÉRIO DA SAÚDE. FUNDAÇÃO NACIONAL DA SAÚDE Ofidismo. Análise epidemiológica. Brasília, Ministério da Saúde; Fundação Nacional da Saúde, 1990

5. BRASIL. MINISTÉRIO DA SAÚDE. FUNDAÇÃO NACIONAL DA SAÚDE - Manual de diagnóstico e tratamento de acidentes por animais peçonhentos. Brasília, Ministério da Saúde; Fundação Nacional da Saúde, 1998.

6. BUCARETCHI, F.; DOUGLAS, J.L.; FONSECA, M.R.C.C.; ZAMBRONE, F.A.D. \& VIEIRA, R.J. - Envenenamento ofídico em crianças: freqüência de reações precoces ao antiveneno em pacientes que receberam pré-tratamento com antagonistas $\mathrm{H} 1 \mathrm{e}$ H2 da histamina e hidrocortisona. Rev. Inst. Med. trop. S. Paulo, 36: 451-457, 1994. 
7. BUCARETCHI, F.; HERRERA, S.R.F.; HYSLOP, S.; BARACAT, E.C.E. \& VIEIRA, R.J. - Snakebites by Bothrops spp in children in Campinas, São Paulo, Brazil. Rev. Inst. Med. trop. S. Paulo, 43: 329-333, 2001.

8. CAMPBELL, J.A. \& LAMAR, W.W. - The venomous reptiles of Latin America. Ithaca, Cornell University Press, 1989

9. CUPO, P.; AZEVEDO-MARQUES, M.M. \& HERING, S.E. - Clinical and laboratory features of South American rattlesnake (Crotalus durissus terrificus) envenomation in children. Trans. roy. Soc. trop. Med. Hyg., 82: 924-929, 1988.

10. CUPO, P.; AZEVEDO-MARQUES, M.M. \& HERING, S.E. - Acute myocardial infarction-like enzyme profile in human victims of Crotalus durissus terrificus envenoming. Trans. roy. Soc. trop. Med. Hyg., 84: 447-451, 1990.

11. CUPO, P.; AZEVEDO-MARQUES, M.M. \& HERING, S.E. - Acidente crotálico na infância: aspectos clínicos, laboratoriais, epidemiológicos e abordagem terapêutica. Rev. Soc. bras. Med. trop., 24: 87-96, 1991.

12. CUPO, P.; AZEVEDO-MARQUES, M.M.; MENEZES, J.B. \& HERING, S.E. - Reações de hipersensibilidade imediatas após uso intravenoso de soros antivenenos: valor prognóstico dos testes de sensibilidade intradérmicos. Rev. Inst. Med. trop. S. Paulo, 33: 115-122, 1991.

13. FAN, H.W.; MARCOPITO, L.F.; CARDOSO, J.L.C. et al. - Sequential randomized and double blind trial of promethazine prophylaxis against early anaphylactic reactions to antivenom for Bothrops snake bite. Brit. med. J., 318: 1451-1452, 1999.

14. JORGE, M.T. \& RIBEIRO, L.A. - Epidemiologia e quadro clínico do acidente por cascavel sul-americana (Crotalus durissus). Rev. Inst. Med. trop. S. Paulo, 34: 347-354, 1992.

15. KAMIGUTI, A.S. \& CARDOSO, J.L.C. - Haemostatic changes caused by the venoms of South American snakes. Toxicon, 27: 955-963, 1989.

16. NISHIOKA, S.A.; JORGE, M.T.; SILVEIRA, P.V. \& RIBEIRO, L.A. - South American rattlesnake bite and soft-tissue infection: report of a case. Rev. Soc. bras. Med. trop., 33: 401-402, 2000.
17. OSHIMA-FRANCO,Y; HYSLOP, S.; PRADO-FRANCESCHI, J.P.; CRUZ-HÖFLING, M.A. \& RODRIGUES-SIMIONI, L. - Neutralizing capacity of antisera raised in horses and rabbits against Crotalus durissus terrificus (South American rattlesnake) venom and its main toxin, crotoxin. Toxicon, 37: 1341-1357, 1999.

18. PREMAWARDHENA, A.P.; DE SILVA, C.E.; FONSEKA, M.M.D.; GUNATILAKE, S.B. \& DE SILVA, H.J. - Low dose subcutaneous adrenaline to prevent acute adverse reactions to antivenom serum in people bitten by snakes: randomized, placebo controlled trial. Brit. med. J., 318: 1041-1043, 1999.

19. REZENDE, N.A.; TORRES, F.M.; DIAS, M.B. et al. - South American rattlesnake bite (Crotalus durissus sp) without envenoming: insights on diagnosis and treatment. Toxicon, 36: 2029-2032, 1998.

20. RIBEIRO, L.A.; ALBUQUERQUE, M.J.; DE CAMPOS, V.A. et al. - Óbitos por serpentes peçonhentas no Estado de São Paulo: avaliação de 43 casos, 1988/1993. Rev. Ass. méd. bras., 44: 312-318, 1998.

21. SANO-MARTINS, I.S.; TOMY, S.C.; CAMPOLINA, D. et al. - Coagulopathy following lethal and non-lethal envenoming of humans by the South American rattlesnake (Crotalus durissus) in Brazil. Quart. J. Med., 94: 551-559, 2001.

22. SALVINI, T.F.; AMARAL, A.C.; MIYABARA, E.H. et al. - Systemic skeletal muscle necrosis induced by crotoxin. Toxicon, 39: 1141-1149, 2001.

23. SILVEIRA, P.V.P. \& NISHIOKA, S.A. - South American rattlesnake bite in a Brazilian teaching hospital. Clinical and epidemiological study of 87 cases, with analysis of factors predictive of renal failure. Trans. roy. Soc. trop. Med. Hyg., 86: 562-564, 1992.

24. SILVEIRA, P.V.P. \& NISHIOKA, S.A. - Venomous snake bite without clinical envenoming ('dry-bite'). A neglected problem in Brazil. Trop. geogr. Med., 47: 82-85, 1995.

25. VITAL-BRAZIL, O. - Venenos ofídicos neurotóxicos. Rev. Ass. méd. bras., 26: 212 218,1980

26. WORLD HEALTH ORGANIZATION - Progress in the characterization of venoms and standardization of antivenoms. Geneva, WHO, 1981. (WHO Offset Publ. No. 58).

Received: 08 January 2002

Accepted: 25 April 2002 